\title{
Animal Models of Alzheimer's Disease: Utilization of Transgenic Alzheimer's Disease Models in Studies of Amyloid Beta Clearance
}

\author{
Tarja Malm • Johanna Magga $\cdot$ Jari Koistinaho
}

Published online: 19 January 2012

(C) The Author(s) 2012. This article is published with open access at Springerlink.com

\begin{abstract}
Glial cells in Alzheimer's disease (AD) have been shown to be capable of clearing or at least restricting the accumulation of toxic amyloid beta $(A \beta)$ deposits. Recently, bone marrow (BM)-derived monocytic cells have been recognized in experimental studies to be superior in their phagocytic properties when compared to their brain endogenous counterparts. In human AD, BM-derived monocytic cells may have deficiencies in their capacity to restrict plaque growth. Therefore, enhancement of phagocytic properties of cells of monocyte origin, both brain endogenous microglia and BM-derived monocytic cells, offers an attractive therapeutic approach to fight off AD. Transgenic mouse models with aberrant $A \beta$ deposition offer a valuable tool for discovery of novel pathways to facilitate cell-mediated $A \beta$ uptake. This article reviews the most recent findings on the phagocytic capacity of cells with monocytic origin in various transgenic AD models and describes the methods to study phagocytic activity of these cells.
\end{abstract}

Keywords Alzheimer's disease · Amyloid precursor protein - Amyloid beta Presenilins - Transgenic mice . Inflammation · Cytokines $\cdot$ Chemokines $\cdot$ Phagocytosis .

T. Malm $\cdot$ J. Magga $\cdot$ J. Koistinaho $(\triangle)$

A.I. Virtanen Institute for Molecular Sciences,

University of Eastern Finland,

P.O. Box 1627, 70211 Kuopio, Finland

e-mail: Jari.Koistinaho@uef.fi

\section{J. Magga}

Institute of Biomedicine, Department of Pharmacology and Toxicology, University of Oulu,

Oulu, Finland

J. Koistinaho

Department of Oncology, Kuopio University Hospital,

Kuopio, Finland
Lysosomes · Microglia B Bone marrow $\cdot$ Macrophages · Aging $\cdot$ Cognitive function

\section{Introduction}

Microglia and bone marrow (BM)-derived monocytic cells have been implicated in Alzheimer's disease (AD) pathogenesis. The role of microglia in the development of AD has for long been under debate. As AD progresses, the magnitude of proinflammatory microglia-secreted cytokines increases, contributing to the vicious cycle of inflammation and following neuronal damage. In addition, some evidence suggests that microglia may actually promote $A \beta$ deposition. On the other hand, whereas microglial phagocytosis of $\mathrm{A} \beta$ in vivo may be rather limited, microglia in vitro are efficient $A \beta$ phagocytes. A subpopulation of brain monocytic cells enters the brain from the circulation upon brain damage. Infiltration of BM-derived cells is very limited in healthy brain and in $\mathrm{AD}$ transgenic mice $[1,2 \cdot \bullet]$ but this infiltration is increased upon injury associated with bloodbrain barrier (BBB) disruption, and infiltrated monocytic cells have been detected in brains of $\mathrm{AD}$ patients who quite often suffer from comorbidities such as small cerebral infarcts [3]. BM-derived cells have been shown to be superior in phagocytosing and clearing $A \beta$ in several different models developed to assess phagocytic activity [4-7]. AD transgenic mice with aberrant $A \beta$ accumulation have been the major cornerstone in studies revealing novel pathways to enhance $A \beta$ clearance. This review article describes the most recent findings on the phenotype of phagocytic cells across different currently available transgenic AD models. In addition, development of methods for assessing the $A \beta$ phagocytic properties is discussed. 


\section{Alzheimer's Disease Animal Models}

$\mathrm{AD}$ research was clearly boosted by the development of transgenic mouse models, and to date, the availability of such models is ample. The obtained pathology of AD mice depends on the transgene, promoter, and mutation of choice; the integration site; and the achieved expression level of the transgene. Human amyloid precursor protein (hAPP) in different length, either 695,751 , or 770 amino acids, have been used as transgenes with several mutations and with either neuron-specific platelet-derived growth factor and Thy-1 promoters or nonneuronal hamster PrP promoter. The onset and severity of $A \beta$ pathology has been indicated to depend on achieved $A \beta 1-42$ levels, with the mutations in APP augmenting the pathology (reviewed in [8]). Whereas mutated APP isoforms seem to be sufficient to cause A $\beta$ deposition, presenilin (PS) 1 or 2 alone are unable to result in any detectable lesions despite the fact that elevation in $A \beta$ levels is observed. Overexpression of mutated PS together with mutated hAPP isoforms aggravates the progression of $A \beta$ pathology with earlier appearance of the plaques. In addition to the APP- and PS-based transgenic mice, transgenic mice carrying mutated tau also have been developed [9]. Overexpression of tau alone is not sufficient to result in plaques, but, together with APP and PS, recapitulates both neurofibrillary tangles and plaques.

Despite the transgene expressed, none of the currently available transgenic mouse models capture the full human AD pathology. However, they are suitable for studies of $A \beta$ phagocytosis due to the facts that

(1) similar to human brain, $A \beta$ deposition increases with aging;

(2) $\mathrm{A} \beta$ in mouse models occurs in similar form as in human $\mathrm{AD}$ brain; compared to human cases, the deposited $A \beta$ in $A D$ transgenic mice is similar in size, and stains with Congo red and Thioflavin $\mathrm{S}$ and also can be found around the vasculature as amyloid angiopathy;

(3) plaques are recognized by glial cells which are recruited around the deposits; and

(4) brain levels of $A \beta$ in these models correlate, at least to some extent, with the severity of cognitive impairment (nicely reviewed by Duyckaerts et al. [8]).

\section{Microglial Phenotype in Alzheimer's Disease Models}

Microglia are the main immunological effector cells with phagocytic properties in the brain. The origin of microglia has long been suggested to lay on the hematopoietic progenitor cells; however, recent reports show that microglia derive from primitive myeloid progenitors at early embryonic life but later are maintained with minimal contribution of hematopoietic cells of peripheral origin [10,11]. Microglia are difficult to be distinguished from other myeloid subsets, however, very recently microglia was reported to express fractalkine receptor CX3CR1, but not the chemokine receptor CCR2, from embryonic stage throughout life [11]. The phenotype of microglia had long been referred to as being either active or resting; however, it now is widely recognized that microglia display various forms of activation states and are never resting, but rather constitutively survey the brain parenchyma for pathogens. Microglial phenotypes are being categorized into $\mathrm{M} 1$ and M2; the latter also referred to alternative activation. M2 activation state has been further subcategorized into M2a, $\mathrm{M} 2 \mathrm{~b}$, and M2c, but most likely any category is not able to fully capture the microglial function because microglia may have unique activation properties depending on the type of stimuli [12].

Microglia in AD mice have been proposed to exert proinflammatory phenotype. Exogenously added $A \beta$ has been shown to promote the production of several proinflammatory mediators, such as interleukin (IL)- $1 \beta$, IL-6, tumor necrosis factor (TNF)- $\alpha$, macrophage inflammatory protein-1 (MIP-1), A $\beta$ degrading enzymes, prostanoids, complement proteins, and free radicals [13]. On the other hand, microglia recognize and respond differently even to different forms of $A \beta$. Oligomeric, the more toxic form of $A \beta$, has been shown to cause M1 shift in microglial phenotype compared to fibrillar form of the peptide [14]. In addition, preexisting activation state achieved with anti-inflammatory cytokines reduces microglial reactivity to $A \beta$ [14].

Several proinflammatory cytokines, such as IL-6, TNF$\alpha$, and IL- $1 \beta$, have been shown to be increased In brains of human $\mathrm{AD}$ patients $[13,15]$. The situation is similar in $\mathrm{AD}$ transgenic mouse models. The overall levels of proinflammatory cytokines of microglial secretion seem to be upregulated, indicating a classical, cytotoxic activity of microglia, though detected cytokines and the time point of their upregulation may vary from model to model. Several studies have assessed microglial cytokine secretion [16-18] from whole brain homogenates or brain total microglia, but because other brain cells are equally capable in secreting the same cytokines as microglia and microglia may differ in their cytokine secretion depending on their surroundings, more cell-specific studies are clearly needed. Aging also may cause a shift in microglial phenotype [19]. Table 1 lists the cytokine expression profile of some commonly used AD transgenic models. In most models, $A \beta$ accumulation precedes the upregulation of cytokines. Indeed, $A \beta$-laden milieu causes a shift in microglial phenotype, which may depend on not only the total brain $A \beta$ pathology but also the microenvironment the microglial cell encounters [19, 20]. Bolmont et al. [20] showed that microglia in the vicinity of plaques are actively taking up additionally 
Table 1 Microglial cytokine expression profiles in some Alzheimer's disease mouse models

\begin{tabular}{|c|c|c|c|c|}
\hline Study & AD mouse model & $\begin{array}{l}\text { Development of } \\
\mathrm{A} \beta \text { pathology }\end{array}$ & Detection method & Cytokine expression profile \\
\hline Masoumi et al. [80] & APPswe/PS1dE9 & 4 months & $\mathrm{IHC}$ & $\begin{array}{l}\text { TNF- } \alpha \uparrow \text { starting at age } 8 \text { mo and } \\
\text { IL- } 1 \beta \text {, IL- } 6 \text {, and MCP- } 1 \uparrow \text { starting } \\
\text { at age } 10 \text { mo }\end{array}$ \\
\hline Hoozemans et al. [15] & APPswe/PS1dE9 & 4 months & Isolated microglia; qPCR & $\begin{array}{l}\text { SRA, CD36, RAGE, insulysin, } \\
\text { neprilysin, and } \\
\text { MMP- } \downarrow ; \text { IL- } 1 \beta \text { and TNF- } \alpha \uparrow \\
\text { starting at age } 8 \text { mo }\end{array}$ \\
\hline Farfara et al. [81] & Tg2576 & 9-11 months & IHC; in situ hybridization & $\begin{array}{l}\text { IFN- } \gamma \text { and IL- } 12 \uparrow \text { and IL- } 4 \downarrow \text { starting } \\
\text { at age } 9 \text { mo }\end{array}$ \\
\hline Jankowsky et al. [16] & APPswe; APP/PS1 & $\begin{array}{l}11 \text { months in APPswe; } \\
10 \text { weeks in APP/PS1 }\end{array}$ & $\begin{array}{l}\text { Organotypic slice cultures; } \\
\text { multiplex cytokine assay }\end{array}$ & $\begin{array}{l}\text { IL- } 1 \alpha, \text { TNF- } \alpha, \text { GM-CSF, and IL- } 6 \uparrow \\
\text { at age } 15 \text { mo in both models. } \\
\text { APP/PS1 brain slices produced } \\
\text { significantly more IL-12p } 40 \text {, IL-1 } 1 \beta \text {, } \\
\text { IL-1 } \alpha \text {, TNF- } \alpha \text {, GM-CSF, and IL- } 6 \\
\text { compared to APPswe brain slices. } \\
\text { Cytokine levels correlated with brain } \\
\text { A } \beta \text { in both models }\end{array}$ \\
\hline Hickman et al. [17] & $\begin{array}{l}\text { PS1(M146L) x } \\
\text { APP751sl }\end{array}$ & $3-4$ months & Brain homogenates; qPCR & $\begin{array}{l}\text { TNF } \alpha \text {, iNOS, IL- } 1 \beta \text {, FASL, TRAIL, } \\
\text { nox } 1 \text {, and Cox } 2 \uparrow \text { at age } 18 \text { mo. } \\
\text { IL- } 1 \beta \uparrow \text { at age } 12 \text { mo }\end{array}$ \\
\hline Hickman et al. [17] & $\begin{array}{l}\text { PS1(M146L) x } \\
\text { APP751sl }\end{array}$ & $3-4$ months & IHC & $\begin{array}{l}\text { Microglia in the near vicinity of A } \beta \\
\text { plaques were shown to adopt an } \\
\text { incomplete alternative activation } \\
\text { state characterized by elevation of } \\
\text { YM- } 1 \text { and absence of TNF- } \alpha \text { and } \\
\text { iNOS at age } 18 \text { mo }\end{array}$ \\
\hline
\end{tabular}

$A \beta$ beta amyloid; $A D$ Alzheimer's disease; FASL Fas ligand; GM-CSF granulocyte-macrophage colony-stimulating factor; IFN- $\gamma$ interferongamma; IHC immunohistochemistry; $I L$ interleukin; $i N O S$ inducible nitric oxide synthase; $M C P$ monocyte chemotactic protein-1; $M M P-9$ matrix metalloproteinase 9; $q P C R$ quantitative polymerase chain reaction; $R A G E$ receptor for advanced glycation endproducts; $S R A$ scavenger receptor A; $T N F-\alpha$ tumor necrosis factor alpha; TRAIL TNF-related apoptosis-inducing ligand

injected $A \beta$ dye in contrast to microglia further away from the plaques and in brains of wild-type controls, suggesting a polarized surrounding-dependent activation and phagocytic capacity of microglia in AD mouse brain. Also, neurotransmitters and neuropeptides may modulate microglial activity and $\mathrm{A} \beta$ phagocytosis $[21,22]$. A deeper knowledge of the microglial activation properties is urgently needed to fully understand how microglial activation status could be adjusted toward more efficient phagocytosis without risking other, important properties of microglia in $\mathrm{AD}$ brain.

\section{Bone Marrow-derived Monocytic Cells in Alzheimer's Disease Models}

Several studies have failed to show efficient microglial in vivo $A \beta$ phagocytosis without additional stimulus, yet increasing evidence shows that peripheral macrophages and monocytic cells are competent phagocytes. These cells have their origin in the BM, where they develop from hematopoietic stem cells (HSC). Upon stimuli, monocytic cells are released from BM into the circulation. Monocytes in the bloodstream are rather short-living and infiltrate into the target tissues followed by cytokine and chemokine secretion. The Ly6 $\mathrm{C}^{+} \mathrm{CCR} 2^{+}$monocytes have been shown to be the direct infiltrating precursors of BM-derived microglia in the brain, with the chemokine CCL2 being the major contributor in mediating the infiltration. Infiltrating COX-2 immunoreactive monocytic cells containing intracellular $A \beta$ also have been found in human AD brain [23]. Similar to brain microglia, BM-derived cells also have been categorized based on their activation state and expression of cell surface molecules. Roughly, proinflammatory Ly $6 \mathrm{C}^{+}$monocytes are recruited in inflamed tissue mediated by CCL2-CCR2 interaction, whereas $\mathrm{Ly} 6 \mathrm{C}^{-}$monocytes are thought to be recruited at the resolving phase of the insult mediated by CX3CR1 and take part in wound repair and tissue remodeling processes [24, 25] .

Whether or not microglia phagocytose $A \beta$ in $A D$ brain or contribute to $A \beta$ accumulation is not yet clear; however, several lines of evidence suggest that BM monocytic cells are efficient phagocytes in vitro and in vivo [26-28]. In addition, there is evidence that monocytes in patients with $A D$ have deficient capacity to phagocytose $A \beta$ [29]. Although $A \beta$ pathology itself may not be sufficient in increasing the infiltration of BM-derived monocytic cells in $\mathrm{AD}$ transgenic mouse brain $[2 \bullet \cdot], \mathrm{AD}$ patients frequently 
suffer from comorbidities such as cerebral infarcts, which are associated with BBB damage. Therefore, it is likely that BM-derived monocytic cell infiltration occurs in human $\mathrm{AD}$. In addition, $\mathrm{CD} 11 \mathrm{~b}^{+}$myeloid cells have been shown to infiltrate into $\mathrm{AD}$ transgenic mouse brain when infused into the bloodstream [30•]. Even without parenchymal infiltration, BM-derived cells may have an important function as $A \beta$ phagocytizing perivascular macrophages, the absence of which was associated with increased cerebral amyloid angiopathy (CAA) and mortality in CCR2-deficient AD mice [2••].

\section{A $\beta$ Phagocytosis and Degradation in Alzheimer's Disease}

In familial cases of $\mathrm{AD}$, imbalance in the production and clearance of $A \beta$ leads to harmful responses to specific $A \beta$ species in neurons and glia, $A \beta$ accumulation, and, eventually, progressive neurodegeneration [31]. Even small chronic deficits in the mechanisms of $A \beta$ reduction may lead to aberrant $A \beta$ accumulation. Dysfunctions in $A \beta$ clearance by microglia or BM-derived monocytic cells in the brain parenchyma, $A \beta$ egress from brain to blood, or $A \beta$ clearance by perivascular macrophages and peripheral blood monocytes may contribute to increased $A \beta$ burden. Depending on the site of $A \beta$ accumulation, it can be referred to as parenchymal $A \beta$ deposition or CAA. Although these conditions have different appearances and possibly altered disease severity, they probably carry similar pathological mechanisms, which also may work in parallel.

The role of microglia in the regulation of $A \beta$ levels in $\mathrm{AD}$ has been under intensive investigation. Depending on conditions, glial cells may have a role in $\mathrm{AD}$ by potentially contributing to increased $A \beta$ burden [32]. However, microglia as brain mononuclear phagocytes have been shown to participate in $A \beta$ reduction with multiple mechanisms. Microglia are able to secrete various proteases such as neprilysin, insulin-degrading enzyme, angiotensin-converting enzyme, cathepsin B, cystatin C, and matrix metalloproteases (MMPs), which may degrade $A \beta$, among other biologically active peptides [31]. After stating this, in this context we concentrate on $\mathrm{A} \beta$ removal by phagocytic mechanisms by myeloid cells including microglia.

Microglia take up soluble $A \beta$ species through nonsaturable fluid phase macropinocytosis and traffic them into the late endosomes and lysosomes for degradation [33]. Oligomeric $A \beta$ uptake by microglia involves recognition of $A \beta$ by scavenger receptors, followed by $\mathrm{A} \beta$ internalization, trafficking to lysosomes, and degradation by lysosomal proteases including cathepsin $B$ [34]. Fibrillar $A \beta$ is recognized by cell surface innate immune receptors, including scavenger receptors and toll-like receptors (TLR), and taken up by receptor-mediated phagocytosis or endocytosis
[35-37] . Also, some other receptors have been linked to fibrillar $A \beta$ phagocytosis, such as a Dap12-associated receptor called signal regulatory protein- $\beta 1$ (SIRP $\beta 1$ ) [38] or triggering receptor expressed on myeloid cells (TREM2) [39], low density lipoprotein (LDL) receptor, and apolipoprotein E (apoE), as reviewed by $\mathrm{Bu}$ [40]. Specifically, macrophages from ApoE2 mice are more efficient in degrading $A \beta$ than ApoE3 macrophages, which in turn are better phagocytes than ApoE4 macrophages [41•].

Low activity of lysosomal enzymes in microglia in comparison to macrophages may account for the limited microglial degradation of $A \beta[6]$. The question remains as to what extent microglia are able to degrade fibrillar $A \beta$ and whether monocytes derived from the periphery would outweigh parenchymal microglia in $A \beta$ clearance in vivo. In addition to limited phagocytosis, microglial capacity for efficient $A \beta$ degradation also may be limited [42]. Even though microglia in the $\mathrm{AD}$ brain and similarly in $\mathrm{AD}$ mouse brain can take up $\mathrm{A} \beta$, their $A \beta$ removal capacity is not sufficient to prevent the accumulation of plaques without any intervention. Thus, interventions aiming at facilitating the uptake and degradation of $A \beta$ by microglial cell are an attractive therapeutic approach.

\section{In Vitro Methods in Studying A $\beta$ Phagocytosis in Alzheimer's Disease Models}

The phagocytosis of $A \beta$ is in its simplest form studied by incubating cells with recombinant $A \beta$ peptides and quantifying uptake and degradation of $A \beta$ peptide from the cells. The fact that $A \beta$ peptides are prone to aggregation, the origin of $A \beta$ preparation, and the way $A \beta$ is solubilized may obviously cause a lot of variation in the outcome of the form of $A \beta$ that is finally applied on the cells. This may explain high variation in the responses to $A \beta$ detected between different cell culture studies. There are many secondary cell lines utilized as models of inflammatory cells, such as immortalized microglia cell lines BV-2, N9, MMGT12, and C8-B4 from mouse origin; HAPI from rat origin; and HMO6 and CHME3 from human origin, as well as macrophage cell line RAW264.7 of mouse origin and monocyte cell line THP-1 of human origin. BV-2 microglia is one of the most utilized cell lines in $A \beta$ phagocytosis studies in vitro [43, 44].

Secondary cells have many similarities but also several differences to primary microglia [43-45], which are one step closer to native microglia. Primary microglia can be obtained from neonatal or adult rodents [46-48] as well as postmortem human brain [49]. Neonatal microglia, a model widely used to study microglia function, actually consist of subpopulations of cells displaying partially different functions $[28,50,51]$. Neonatal microglia also may have immature responses to inflammatory stimulus compared to adult 
microglia, which have decline in proteasomal function and reduced $A \beta$ phagocytosis $[46,52]$. Also, microglia obtained from aged animals show altered responses to inflammation and decreased $A \beta$ uptake and phagocytosis in comparison to microglia isolated from young adult animals [48]. Aged animals also have reduced expression of $\mathrm{A} \beta$-binding receptors and $\mathrm{A} \beta$-degrading enzymes [17]. Primary monocytes can be obtained from mouse BM or human peripheral blood, or from HSC by differentiation with macrophage colony-stimulating factor (MCSF) [28, 53]. Macrophages can be collected from mouse peritoneum after induced inflammatory stimulus or by spontaneous or MCSF-induced differentiation of primary monocytes in vitro [6, 28, 29, 41•, 54].

For the simplest $A \beta$ uptake studies, cells are incubated with a fluorochrome-conjugated $A \beta$, which can be tracked inside the cells using fluorescent microscopy or quantified by flow cytometry [28, 29, 33, 41•]. To study degradation of internalized $A \beta$, quantification of remaining $A \beta$ protein levels within the cells is recommended instead of fluorescence signal to ensure that the readout is true $A \beta$ clearance and not just fadeout of the fluorochrome. Phagocytosis in general also can be studied by feeding the cells with fluorescent beads or latex beads; however this is a nonspecific assay for overall phagocytic activity.

\section{Ex Vivo Methods in Studying A $\beta$ Phagocytosis in Alzheimer's Disease Models}

To expose the cells into a more authentic environment for $\mathrm{A} \beta$ phagocytosis, the cells may be applied on top of brain sections prepared from aged transgenic AD mice containing native $A \beta$ deposits $[28,41 \cdot, 55,56]$. The reduction in $A \beta$ burden can be determined by immunohistochemical $A \beta$ staining as well as quantification of protein levels. The sections also may be obtained from postmortem samples from $\mathrm{AD}$ patients as a more suitable model for studying $\mathrm{A} \beta$ phagocytosis when cells of human origin are investigated. The ex vivo $A \beta$ phagocytosis assay is superior to $A \beta$ uptake assay in regard to the exposure of cells into native $A D$ brain conditions, which may modulate the cell phenotype mimicking the in vivo situation. Preferably, cells of various origin and alternative methods should be combined when studying the mechanisms of $\mathrm{A} \beta$ phagocytosis.

\section{In Vivo Methods in Studying $A \beta$ Phagocytosis in Alzheimer's Disease Models}

Finally, the most relevant model for $A \beta$ phagocytosis is to utilize transgenic mouse models of AD. To study the role of specific factors involved in the $\mathrm{A} \beta$ clearance, transgenic $\mathrm{AD}$ mice have been crossbred with mouse strains lacking or overexpressing certain protein products. Because knocking out specific genes may have developmental consequences or, on the other hand, the gene function may be compensated by other factors, it is an advantage to utilize conditional transgene technology. With this technology, the expression of a particular gene is conditional to a specific stimulus and can be switched "on" or "off" as desired. This has been utilized with $\mathrm{AD}$ models in order to ablate a certain type of cell to study their contribution to AD pathology $[4,57,58]$.

First studies showing the infiltration of peripheral myeloid cells in $\mathrm{AD}$ mouse brain have taken advantage of the chimeric mouse model. In this model, recipient mice are irradiated and their blood cell production is reconstituted by transplantation of either purified HSC or crude leukocyte population including HSC. Donor mice expressing a reporter gene, such as green fluorescent protein, have been utilized to track the peripheral derived cells from the brain. Although the method is widely used [4, 26, 59], the irradiation in the chimeric model has been legitimately criticized for causing preconditioning leading to increased permeability of $\mathrm{BBB}$ and excessive peripheral cell infiltration into the brain parenchyma $[1,2 \cdot \bullet]$. Other approaches have been to transplant the cells to naive mouse circulation or locally into the brain to study their $A \beta$ phagocytosis $[28,30 \bullet, 60]$.

$\mathrm{A} \beta$ burden in the brain can be quantified with immunohistochemical staining for total $A \beta$ or with Congo red staining for fibrillar $A \beta$ plaques. The levels of soluble and insoluble $A \beta$ species may be determined from the brain and blood with enzyme-linked immunosorbent assay. Because $\mathrm{AD}$ pathology and $\mathrm{A} \beta$ deposition occur in transgenic mice within months and may require as long as $1-2$ years to fully develop, there is a demand for methods that would allow monitoring the $\mathrm{A} \beta$ burden in longitudinal studies. Recent progresses in neuroimaging techniques enable this monitoring in vivo. Positron emission tomography with $A \beta$ tracers can be utilized to directly visualize $A \beta$ in vivo [61]. Also, the development of magnetic resonance imaging techniques has led to promising results in visualization of $A \beta$ deposits [62]. A $\beta$ deposition and interaction with cells can be monitored in brain in vivo utilizing multiphoton microscopy $[20,63,64 \bullet \cdot]$. In general, alterations in $A \beta$ burden can be monitored in parallel with behavioral studies to link it to possible changes in memory deficits and anxiety. However, the $\mathrm{A} \beta$ burden and learning deficits do not necessarily correlate because other mechanisms or specific forms of $A \beta$ may engage to these processes [65-68] . The findings on the mechanisms of $A \beta$ phagocytosis in AD models will be discussed in more detail in the next paragraph. 
Table 2 Role of specific myeloid cells or factors regulating myeloid cell migration or activity affiliated to $\mathrm{A} \beta$ clearance in the animal models of $\mathrm{AD}$

\begin{tabular}{|c|c|c|c|}
\hline Study & Cells & Model & Effect on $A \beta$ burden \\
\hline Mildner et al. $[2 \cdot \bullet]$ & $\mathrm{BM} \mathrm{CCR}^{+}$cells & $\begin{array}{l}\mathrm{CCR} 2^{-/-} \mathrm{BM} \text { cell chimera in } \\
\mathrm{APP} \text { swe } / \mathrm{PS} 1 \text { and } \mathrm{Tg} 2576 \\
\text { mice }\end{array}$ & $\begin{array}{l}\text { Irradiation preconditioning and CCR2 expression } \\
\text { in } \mathrm{BM} \text { cells are required for their brain } \\
\text { engraftment. Peripheral macrophages rather than } \\
\text { parenchymal microglia modulate } \mathrm{A} \beta \text { deposition } \\
\text { in } \mathrm{AD} \text { mice }\end{array}$ \\
\hline El Khoury et al. [5] & $\mathrm{CCR} 2$ & $\begin{array}{l}\mathrm{CCR} 2^{-/} \text {mice crossed with } \\
\mathrm{Tg} 2576 \text { mice }\end{array}$ & $\begin{array}{l}\text { Absence of CCR2 impairs microglia accumulation } \\
\text { and increases A } \beta \text { levels and mortality in AD } \\
\text { mice }\end{array}$ \\
\hline Magga et al. [28] & 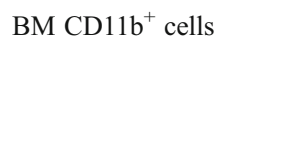 & $\begin{array}{l}\text { Adoptive transfer of neprilysin- } \\
\text { transfected BM CD11 } \mathrm{b}^{+} \text {cells } \\
\text { into APP/PS1mice }\end{array}$ & $\begin{array}{l}\mathrm{BM} \mathrm{CD} 11 \mathrm{~b}^{+} \text {cells home to } \mathrm{AD} \text { mouse brain after } \\
\text { adoptive transfer. Injection of } \mathrm{CD} 11 \mathrm{~b}^{+} \text {cells } \\
\text { expressing secreted form of neprilysin is } \\
\text { associated with reduced } \mathrm{A} \beta \text { burden }\end{array}$ \\
\hline $\begin{array}{l}\text { Koistinaho } \\
\text { et al. [56] }\end{array}$ & Microglia/CD11 b cells & $\begin{array}{l}\mathrm{CD} 11 \mathrm{~b}^{+} \text {cell ablation in APPPS1 } \\
\text { and APP23 mice }\end{array}$ & $\begin{array}{l}\text { Nearly complete ablation of } C D 11 b^{+} \text {cells did not } \\
\text { alter } A \beta \text { levels in } A D \text { mice within the } \\
\text { observation period of } 4 \text { weeks }\end{array}$ \\
\hline Ruan et al. [82] & CD11 $\mathrm{c}^{+}$TGF $-\beta^{+}$cells & $\begin{array}{l}\text { Dominant negative TGF- } \beta \text { in } \\
\text { CD11 }{ }^{+} \text {cells in Tg2576 and } \\
\text { APPswe/PS1dE9 mice }\end{array}$ & $\begin{array}{l}\text { TGF- } \beta \text { deficiency in } \mathrm{CD} 11 \mathrm{c}^{+} \text {reduced } \\
\text { parenchymal and vascular } \mathrm{A} \beta \text { burden involving } \\
\text { infiltration of peripheral macrophages }\end{array}$ \\
\hline Abbas et al. [83] & $\mathrm{CD} 45$ & $\begin{array}{l}\mathrm{CD} 45^{-/-} \text {crossed with } \\
\text { APPswe/PS1dE9 mice }\end{array}$ & $\begin{array}{l}\text { CD45 deficiency promotes proinflammatory } \\
\text { microglial activation, reduces their phagocytic } \\
\text { activity, and increases soluble and insoluble } \mathrm{A} \beta \\
\text { levels }\end{array}$ \\
\hline Town et al. [84] & $\begin{array}{l}\text { Myeloid differentiation } \\
\text { factor } 88\end{array}$ & $\begin{array}{l}\text { MyD88 }^{-/} \text {BM cell chimera in } \\
\text { TgCRND8 and APPswe/PS1dE9 } \\
\text { mice }\end{array}$ & $\begin{array}{l}\text { MyD88 deletion in } \mathrm{BM} \text { cells attenuates } \\
\text { neuroinflammation, enhances } \mathrm{A} \beta \text { phagocytosis, } \\
\text { and reduces } \mathrm{A} \beta \text { burden }\end{array}$ \\
\hline $\begin{array}{l}\text { Zhu et al. [85] and } \\
\text { Hao et al. [86] }\end{array}$ & $\mathrm{CX} 3 \mathrm{CR} 1$ & $\begin{array}{l}\mathrm{CX} 3 \mathrm{CR} 1^{-/} \text {crossed with APPPS } 1 \\
\text { mice }\end{array}$ & $\begin{array}{l}\text { Absence of CX3CR } 1 \text { leads to altered } \\
\text { inflammation, enhancement of microglia } A \beta \\
\text { phagocytosis, and reduction of } A \beta \text { burden }\end{array}$ \\
\hline Lee et al. [87] & CD14 & $\mathrm{CD} 14^{-/-}$crossed with APPswe/PS1dE9 mice & $\begin{array}{l}\text { TLR co-receptor CD14 deficiency alters } \\
\text { microglia activation and reduces microgliosis } \\
\text { and } A \beta \text { burden }\end{array}$ \\
\hline Liu et al. [88] & TLR4 & $\begin{array}{l}\text { TLR4 mutation mice crossed with } \\
\text { APPswe/PS1dE9 mice }\end{array}$ & $\begin{array}{l}\text { TLR mutation decreases microglia activation and } \\
\text { increases } A \beta \text { deposition in early AD possibly } \\
\text { involving reduced } A \beta \text { clearance }\end{array}$ \\
\hline $\begin{array}{l}\text { Reed-Geaghan } \\
\text { et al. [89] }\end{array}$ & TLR9 ligand & $\begin{array}{l}\text { TLR9 ligand CpG injection (i.c.v) } \\
\text { into Tg2576 mice }\end{array}$ & $\begin{array}{l}\text { TLR9 ligand } \mathrm{CpG} \text { reduces } \mathrm{A} \beta \text { burden and } \\
\text { increases microglial production of degrading } \\
\text { enzymes and reduction of } \mathrm{A} \beta\end{array}$ \\
\hline Song et al. [90] & EP2 & $\begin{array}{l}\mathrm{EP}^{-/} \text {BM cell chimera in APPswe/ } \\
\text { PS1dE9 mice }\end{array}$ & EP2 deletion in BM cells reduces $A \beta$ burden \\
\hline $\begin{array}{l}\text { Doi et al. [91] and } \\
\text { Keene et al. [92] }\end{array}$ & Liver $\mathrm{X}$ receptor & $\begin{array}{l}\text { LXR agonist p.o. into APP } 23 \text { mice, } \\
\text { LXR }^{-1} \text { crossed with APPswe/PS1dE9 } \\
\text { mice }\end{array}$ & $\begin{array}{l}\text { LXR agonist reduces } A \beta \text { burden in } \mathrm{AD} \text { mice on } \\
\text { high-fat diet. Astrocytic } \mathrm{LXR} \text { activation and the } \\
\text { release of } A \text { poE are involved in microglial } \mathrm{A} \beta \\
\text { phagocytosis }\end{array}$ \\
\hline Terwel et al. [93] & $\begin{array}{l}\text { Complement } \\
\text { factor C3 }\end{array}$ & $\mathrm{C}^{-1-}$ crossed with APP mice & $\begin{array}{l}\text { Absence of } \mathrm{C} 3 \text { drives microglia into } \mathrm{M} 2 \\
\text { alternative activation phenotype and increases } \\
\mathrm{A} \beta \text { burden }\end{array}$ \\
\hline Fitz et al. [94] & IL-6 & $\begin{array}{l}\text { AAV1-induced IL-6 overexpression in } \\
\text { brain of TgCRND8 and Tg2576 mice }\end{array}$ & $\begin{array}{l}\text { Overexpression of IL- } 6 \text { leads to massive gliosis, } \\
\text { and attenuates } A \beta \text { deposition by enhanced } \\
\text { microglia activation and possibly by increased } \\
A \beta \text { phagocytosis }\end{array}$ \\
\hline Maier et al. [95] & IL-1 $\beta$ & $\begin{array}{l}\text { Overexpression of IL-1 } \beta \text { in brain of } \\
\text { APPswe/PS1dE9 mice }\end{array}$ & $\begin{array}{l}\text { Sustained overexpression of IL- } 1 \beta \text { enhances } \\
\text { microglia activation and reduces } A \beta \text { burden }\end{array}$ \\
\hline $\begin{array}{l}\text { Chakrabarty } \\
\text { et al. [96] }\end{array}$ & MCSF & $\begin{array}{l}\text { Weekly i.p. injections of MCSF into } \\
\text { APPswe/PS1 }\end{array}$ & $\begin{array}{l}\text { MCSF increases microgliosis and BM cell } \\
\text { infiltration and reduces } A \beta \text { burden by } \\
\text { phagocytosis }\end{array}$ \\
\hline
\end{tabular}

$A \beta$ beta amyloid; $A A V$ adeno associated virus; $A D$ Alzheimer's disease; apoE apolipoprotein E; $B M$ bone marrow; $E P 2$ prostaglandin E2 receptor subtype 2; i.c.v. intracerebroventricular; $I L$ interleukin; i.p. intraperitoneal; $L X R$ liver x receptor; MCSF macrocyte colony-stimulating factor; p.o. per oral; $T G F-\beta^{+}$transforming growth factor beta; TLR 9 toll-like receptor 9 


\section{Mechanisms of A $\beta$ Phagocytosis in Myeloid Cells in Alzheimer's Disease Models}

Microglia-mediated clearance of $A \beta$ in vivo may be rather limited, but it can be enhanced by opsonization of $A \beta$ deposits obtained with active or passive immunotherapy. Enhanced $A \beta$ clearance in turn associates with alleviation of AD-related neuropathological alterations (reviewed in [69]). The A $\beta$-antibody complex is identified with $\mathrm{Fc}$ receptors present in immune cells, including microglia and macrophages subsequently leading to $\mathrm{Fc}$ receptor-mediated phagocytosis (reviewed in [70]). However, microglia-mediated A $\beta$ phagocytosis does not explain all the beneficial effects of immunization because other mechanisms, such as altered $A \beta$ fibrillization in brain parenchyma or enhanced brain to blood efflux of $A \beta$ also may occur (reviewed in [69]).

Although the immunotherapy treatment for $\mathrm{AD}$ is promising, it is hindered by severe adverse effects such as brain microhemorrhages observed in animal studies and encephalitis observed in clinical trials after passive and active immunization, respectively, as reviewed in [69]. It has been reported that macrophages laden with $A \beta$ may get trapped to endothelial layer, inhibiting the monocyte emigration and $A \beta$ export across BBB [53], possibly partly explaining the increased occurrence of hemorrhages. There are naturally occurring autoantibodies to $A \beta$ in plasma and cerebrospinal fluid that exist in both healthy individuals as well as in AD patients although their levels may be decreased in advanced $A D$ as well as within normal aging [71, 72] . Because these autoantibodies promote microglia-mediated uptake and clearance of $\mathrm{A} \beta[73,74]$ and bind to $\mathrm{A} \beta$ deposits in human $\mathrm{AD}$ brain [75] and after peripheral administration in animal models in vivo [74], they may offer a more native therapeutical approach to combat towards $\mathrm{A} \beta$. An alternative vaccination strategy also was described with glatiramer acetate, a weak agonist of autoantigens, involving recruitment of BM-derived dendritic cells and their regulation of $A \beta$ deposition $[57,76]$.

Findings on certain cell types, receptors, or pharmacological treatments associated with $\mathrm{A} \beta$ clearance by microglia or monocytic cells in animal models of AD are represented in Table 2. Many pharmacological approaches such as galantamine [77], valproic acid [78], and cannabinoids [79] have been shown to enhance phagocytosis and potentially, clearance of $A \beta$ in mouse microglial or monocytic cells in vitro. Pharmacological approach with curcuminoids also was shown to result in $\mathrm{A} \beta$ clearance by human monocytes obtained from AD patients $[29,80]$, suggesting that in vitro models of $A D$ may be applicable to study monocytic function in AD. Furthermore, therapeutical approaches not directly associated with $\mathrm{A} \beta$ phagocytosis may have unexpected effects on microglial function as reported for galantamine and $\gamma$-secretase inhibitors increasing and inhibiting microglial $\mathrm{A} \beta$ phagocytosis, respectively $[77,81]$.

\section{Conclusions}

Transgenic AD mouse models have revolutionized the research of mechanisms leading to $A \beta$ clearance by cells of myeloid origin. Several in vitro and ex vivo methods assessing the phagocytic capacity of microglia and BM-derived monocytic cells have been developed. Increasing knowledge of the heterogeneity of microglial function in $\mathrm{AD}$ has changed the course of research to not only dampen microglial reactivity but also to modulate their activation properties. Pinpointing such events leading to reduction in brain toxic $A \beta$ levels offers an attractive tool for combating this devastating disease.

Disclosures Dr. Tarja Malm has served as a consultant for Medeia Therapeutics Ltd. and Baxter Innovations GmbH. Dr. Johanna Magga has served as a consultant for Medeia Therapeutics Ltd. and Baxter Innovations GmbH. Dr. Jari Koistinaho has served as a board member and consultant to Medeia Therapeutics Ltd.; has received grants from Medeia Therapeutics Ltd. and Baxter Innovations $\mathrm{GmbH}$; has received travel expense compensation from Baxter Innovations $\mathrm{GmbH}$; and his wife is a CEO of Medeia Therapeutics Ltd.

Open Access This article is distributed under the terms of the Creative Commons Attribution Noncommercial License which permits any noncommercial use, distribution, and reproduction in any medium, provided the original author(s) and source are credited.

\section{References}

Papers of particular interest, published recently, have been highlighted as:

- Of importance

•• Of major importance

1. Mildner A, Schmidt H, Nitsche M, et al. Microglia in the adult brain arise from Ly-6ChiCCR2+ monocytes only under defined host conditions. Nat Neurosci. 2007;10:1544-53.

2. . Mildner A, Schlevogt B, Kierdorf K, et al. Distinct and nonredundant roles of microglia and myeloid subsets in mouse models of Alzheimer's disease. J Neurosci. 2011;31:11159-71. This article describes important findings on myeloid subsets and CCR2 regulating their migration and functional properties in $A D$ model in vivo.

3. Koistinaho M, Koistinaho J. Interactions between Alzheimer's disease and cerebral ischemia-focus on inflammation. Brain Res Brain Res Rev. 2005;48:240-50.

4. Simard AR, Soulet D, Gowing G, et al. Bone marrow-derived microglia play a critical role in restricting senile plaque formation in Alzheimer's disease. Neuron. 2006;49:489-502.

5. El Khoury J, Toft M, Hickman SE, et al. Ccr2 deficiency impairs microglial accumulation and accelerates progression of Alzheimerlike disease. Nat Med. 2007;13:432-8.

6. Majumdar A, Chung H, Dolios G, et al. Degradation of fibrillar forms of Alzheimer's amyloid beta-peptide by macrophages. Neurobiol Aging. 2008;29:707-15.

7. Fiala M, Cribbs DH, Rosenthal M, Bernard G. Phagocytosis of amyloid-beta and inflammation: two faces of innate immunity in Alzheimer's disease. J Alzheimers Dis. 2007;11:457-63. 
8. Duyckaerts C, Potier MC, Delatour B. Alzheimer disease models and human neuropathology: similarities and differences. Acta Neuropathol. 2008;115:5-38.

9. Gotz J, Ittner LM. Animal models of Alzheimer's disease and frontotemporal dementia. Nat Rev Neurosci. 2008;9:532-44.

10. Ginhoux F, Greter M, Leboeuf M, et al. Fate mapping analysis reveals that adult microglia derive from primitive macrophages. Science. 2010;330(6005):841-5

11. Mizutani M, Pino PA, Saederup N, et al. The Fractalkine Receptor but Not CCR2 Is Present on Microglia from Embryonic Development throughout Adulthood. J Immunol. 2011, In press.

12. Mandrekar-Colucci S, Landreth GE. Microglia and inflammation in Alzheimer's disease. CNS Neurol Disord Drug Targets. 2010;9:156-67.

13. Akiyama H, Barger S, Barnum S, et al. Inflammation and Alzheimer's disease. Neurobiol Aging. 2000;21:383-421.

14. Michelucci A, Heurtaux T, Grandbarbe L, et al. Characterization of the microglial phenotype under specific pro-inflammatory and anti-inflammatory conditions: effects of oligomeric and fibrillar amyloid-beta. J Neuroimmunol. 2009;210:3-12.

15. Hoozemans JJ, Veerhuis R, Rozemuller JM, Eikelenboom P. Neuroinflammation and regeneration in the early stages of Alzheimer's disease pathology. Int J Dev Neurosci. 2006;24:157-65.

16. Jankowsky JL, Fadale DJ, Anderson J, et al. Mutant presenilins specifically elevate the levels of the 42 residue beta-amyloid peptide in vivo: evidence for augmentation of a 42-specific gamma secretase. Hum Mol Genet. 2004;13:159-70.

17. Hickman SE, Allison EK, El Khoury J. Microglial dysfunction and defective beta-amyloid clearance pathways in aging Alzheimer's disease mice. J Neurosci. 2008;28:8354-60.

18. Patel NS, Paris D, Mathura V, Quadros AN, et al. Inflammatory cytokine levels correlate with amyloid load in transgenic mouse models of Alzheimer's disease. J Neuroinflammation. 2005;2:9.

19. Jimenez S, Baglietto-Vargas D, Caballero C, et al. Inflammatory response in the hippocampus of PS1M146L/APP751SL mouse model of Alzheimer's disease: age-dependent switch in the microglial phenotype from alternative to classic. J Neurosci. 2008;28:11650-61.

20. Bolmont T, Haiss F, Eicke D, et al. Dynamics of the microglial/ amyloid interaction indicate a role in plaque maintenance. J Neurosci. 2008;28:4283-92.

21. Heneka MT, Nadrigny F, Regen T, et al. Locus ceruleus controls Alzheimer's disease pathology by modulating microglial functions through norepinephrine. Proc Natl Acad Sci U S A. 2010;107:6058-63.

22. Fleisher-Berkovich S, Filipovich-Rimon T, Ben Shmuel S, et al. Distinct modulation of microglial amyloid beta phagocytosis and migration by neuropeptides. J Neuroinflammation. 2010;7:61.

23. Fiala M, Liu QN, Sayre J, et al. Cyclooxygenase-2-positive macrophages infiltrate the Alzheimer's disease brain and damage the blood-brain barrier. Eur J Clin Invest. 2002;32:360-71.

24. Auffray C, Sieweke MH, Geissmann F. Blood monocytes: development, heterogeneity, and relationship with dendritic cells. Annu Rev Immunol. 2009;27:669-92.

25. Malm T, Koistinaho M, Muona A, et al. The role and therapeutic potential of monocytic cells in Alzheimer's disease. Glia. 2010;58:889-900.

26. Malm TM, Koistinaho M, Parepalo M, et al. Bone-marrow-derived cells contribute to the recruitment of microglial cells in response to beta-amyloid deposition in APP/PS1 double transgenic Alzheimer mice. Neurobiol Dis. 2005;18:134-42.

27. Simard AR, Rivest S. Bone marrow stem cells have the ability to populate the entire central nervous system into fully differentiated parenchymal microglia. FASEB J. 2004;18:998-1000.

28. Magga J, Savchenko E, Malm T, et al.: Production of monocytic cells from bone marrow stem cells: therapeutic usage in Alzheimer's disease. J Cell Mol Med 2011, In press.
29. Fiala M, Liu PT, Espinosa-Jeffrey A, et al. Innate immunity and transcription of MGAT-III and Toll-like receptors in Alzheimer's disease patients are improved by bisdemethoxycurcumin. Proc Natl Acad Sci U S A. 2007;104:12849-54.

30. - Lebson L, Nash K, Kamath S, et al. Trafficking CD11b-positive blood cells deliver therapeutic genes to the brain of amyloiddepositing transgenic mice. J Neurosci. 2010;30:9651-8. This article describes an applicable method to modify monocytes to enhance their phagocytic capacity in cell-based therapy in AD model in vivo.

31. De Strooper B. Proteases and proteolysis in Alzheimer disease: a multifactorial view on the disease process. Physiol Rev. 2010;90:46594.

32. Nagele RG, Wegiel J, Venkataraman V, et al. Contribution of glial cells to the development of amyloid plaques in Alzheimer's disease. Neurobiol Aging. 2004;25:663-74.

33. Mandrekar S, Jiang Q, Lee CY, et al. Microglia mediate the clearance of soluble Abeta through fluid phase macropinocytosis. J Neurosci. 2009;29:4252-62.

34. Yang CN, Shiao YJ, Shie FS, et al. Mechanism mediating oligomeric Abeta clearance by naive primary microglia. Neurobiol Dis. 2011;42:221-30.

35. Reed-Geaghan EG, Savage JC, Hise AG, Landreth GE. CD14 and toll-like receptors 2 and 4 are required for fibrillar $\mathrm{A}\{$ beta $\}$-stimulated microglial activation. J Neurosci. 2009;29:11982-92.

36. Richard KL, Filali M, Prefontaine P, Rivest S. Toll-like receptor 2 acts as a natural innate immune receptor to clear amyloid beta 1-42 and delay the cognitive decline in a mouse model of Alzheimer's disease. J Neurosci. 2008;28:5784-93.

37. Koenigsknecht J, Landreth G. Microglial phagocytosis of fibrillar beta-amyloid through a betal integrin-dependent mechanism. J Neurosci. 2004;24:9838-46.

38. Gaikwad S, Larionov S, Wang Y, et al. Signal regulatory proteinbeta1: a microglial modulator of phagocytosis in Alzheimer's disease. Am J Pathol. 2009;175:2528-39.

39. Frank S, Burbach GJ, Bonin M, et al. TREM 2 is upregulated in amyloid plaque-associated microglia in aged APP23 transgenic mice. Glia. 2008;56:1438-47.

40. Bu G. Apolipoprotein E and its receptors in Alzheimer's disease: pathways, pathogenesis and therapy. Nat Rev Neurosci. 2009;10:333-44.

41. - Zhao L, Lin S, Bales KR, et al. Macrophage-mediated degradation of beta-amyloid via an apolipoprotein $\mathrm{E}$ isoform-dependent mechanism. J Neurosci. 2009;29:3603-12. This article describes important findings on ApoE isoform-dependent function of phagocytic cells in A $\beta$ clearance. Also, in vitro and ex vivo methods to study A $\beta$ phagocytosis are nicely covered.

42. Paresce DM, Chung H, Maxfield FR. Slow degradation of aggregates of the Alzheimer's disease amyloid beta-protein by microglial cells. J Biol Chem. 1997;272:29390-7.

43. Horvath RJ, Nutile-McMenemy N, Alkaitis MS, Deleo JA. Differential migration, LPS-induced cytokine, chemokine, and NO expression in immortalized BV-2 and HAPI cell lines and primary microglial cultures. J Neurochem. 2008;107:557-69.

44. Henn A, Lund S, Hedtjarn M, et al. The suitability of BV2 cells as alternative model system for primary microglia cultures or for animal experiments examining brain inflammation. ALTEX. 2009;26:83-94.

45. Nagai A, Nakagawa E, Hatori K, et al. Generation and characterization of immortalized human microglial cell lines: expression of cytokines and chemokines. Neurobiol Dis. 2001;8:1057-68.

46. Floden AM, Combs CK. Beta-amyloid stimulates murine postnatal and adult microglia cultures in a unique manner. J Neurosci. 2006;26:4644-8.

47. Moussaud S, Draheim HJ. A new method to isolate microglia from adult mice and culture them for an extended period of time. $\mathrm{J}$ Neurosci Methods. 2010;187:243-53. 
48. Njie EG, Boelen E, Stassen FR, et al.: Ex vivo cultures of microglia from young and aged rodent brain reveal age-related changes in microglial function. Neurobiol Aging 2010.

49. Walker DG, Lue LF. Investigations with cultured human microglia on pathogenic mechanisms of Alzheimer's disease and other neurodegenerative diseases. J Neurosci Res. 2005;81:412-25.

50. Saura J, Tusell JM, Serratosa J. High-yield isolation of murine microglia by mild trypsinization. Glia. 2003;44:183-9.

51. Shimizu E, Kawahara K, Kajizono M, et al. IL-4-induced selective clearance of oligomeric beta-amyloid peptide(1-42) by rat primary type 2 microglia. J Immunol. 2008;181:6503-13.

52. Stolzing A, Grune T. Impairment of protein homeostasis and decline of proteasome activity in microglial cells from adult Wistar rats. J Neurosci Res. 2003;71:264-71.

53. Zaghi J, Goldenson B, Inayathullah $\mathrm{M}$, et al. Alzheimer disease macrophages shuttle amyloid-beta from neurons to vessels, contributing to amyloid angiopathy. Acta Neuropathol. 2009;117:111-24.

54. Yamamoto M, Kiyota T, Walsh SM, et al. Cytokine-mediated inhibition of fibrillar amyloid-beta peptide degradation by human mononuclear phagocytes. J Immunol. 2008;181:3877-86.

55. Wyss-Coray T, Loike JD, Brionne TC, et al. Adult mouse astrocytes degrade amyloid-beta in vitro and in situ. Nat Med. 2003;9:453-7.

56. Koistinaho M, Lin S, Wu X, et al. Apolipoprotein E promotes astrocyte colocalization and degradation of deposited amyloid-beta peptides. Nat Med. 2004;10:719-26.

57. Butovsky O, Kunis G, Koronyo-Hamaoui M, Schwartz M. Selective ablation of bone marrow-derived dendritic cells increases amyloid plaques in a mouse Alzheimer's disease model. Eur J Neurosci. 2007;26:413-6.

58. Grathwohl SA, Kalin RE, Bolmont T, et al. Formation and maintenance of Alzheimer's disease beta-amyloid plaques in the absence of microglia. Nat Neurosci. 2009;12:1361-3.

59. Stalder AK, Ermini F, Bondolfi L, et al. Invasion of hematopoietic cells into the brain of amyloid precursor protein transgenic mice. $\mathrm{J}$ Neurosci. 2005;25:11125-32.

60. Nikolic WV, Hou H, Town T, et al. Peripherally administered human umbilical cord blood cells reduce parenchymal and vascular beta-amyloid deposits in Alzheimer mice. Stem Cells Dev. 2008; $17: 423-39$.

61. Higuchi M, Maeda J, Ji B, et al. In-vivo visualization of key molecular processes involved in Alzheimer's disease pathogenesis: Insights from neuroimaging research in humans and rodent models. Biochim Biophys Acta. 2010;1802:373-88.

62. Teipel SJ, Kaza E, Hadlich S, et al. Automated detection of amyloid-beta-related cortical and subcortical signal changes in a transgenic model of Alzheimer's disease using high-field MRI. J Alzheimers Dis. 2011;23:221-37.

63. Meyer-Luehmann M, Spires-Jones TL, Prada C, et al. Rapid appearance and local toxicity of amyloid-beta plaques in a mouse model of Alzheimer's disease. Nature. 2008:451:720-4

64. • Hefendehl JK, Wegenast-Braun BM, et al. Long-term in vivo imaging of beta-amyloid plaque appearance and growth in a mouse model of cerebral beta-amyloidosis. J Neurosci. 2011;31:624-9. This article describes an in vivo method for long-term tracking on single $A \beta$ deposits over time. Revealing the dynamics of A $\beta$ deposition is of high importance in understanding the disease mechanisms and for evaluation of AD therapy.

65. Malm T, Ort M, Tahtivaara L, et al. beta-Amyloid infusion results in delayed and age-dependent learning deficits without role of inflammation or beta-amyloid deposits. Proc Natl Acad Sci U S A. $2006 ; 103: 8852-7$

66. Malm TM, Iivonen H, Goldsteins G, et al. Pyrrolidine dithiocarbamate activates Akt and improves spatial learning in APP/PS1 mice without affecting beta-amyloid burden. J Neurosci. 2007;27:3712-21.
67. Cheng IH, Scearce-Levie K, Legleiter J, et al. Accelerating amyloid-beta fibrillization reduces oligomer levels and functional deficits in Alzheimer disease mouse models. J Biol Chem. 2007;282:23818-28.

68. Lesne S, Kotilinek L, Ashe KH. Plaque-bearing mice with reduced levels of oligomeric amyloid-beta assemblies have intact memory function. Neuroscience. 2008;151:745-9.

69. Morgan D. Immunotherapy for Alzheimer's disease. J Intern Med. 2011;269:54-63.

70. Okun E, Mattson MP, Arumugam TV. Involvement of Fc receptors in disorders of the central nervous system. Neuromolecular Med. 2010;12:164-78.

71. Du Y, Dodel R, Hampel H, et al. Reduced levels of amyloid betapeptide antibody in Alzheimer disease. Neurology. 2001;57:8015 .

72. Britschgi M, Olin CE, Johns HT, et al. Neuroprotective natural antibodies to assemblies of amyloidogenic peptides decrease with normal aging and advancing Alzheimer's disease. Proc Natl Acad Sci U S A. 2009;106:12145-50.

73. Istrin G, Bosis E, Solomon B. Intravenous immunoglobulin enhances the clearance of fibrillar amyloid-beta peptide. J Neurosci Res. 2006;84:434-43.

74. Magga J, Puli L, Pihlaja R, et al. Human intravenous immunoglobulin provides protection against Abeta toxicity by multiple mechanisms in a mouse model of Alzheimer's disease. J Neuroinflammation. 2010;7:90.

75. Kellner A, Matschke J, Bernreuther C, et al. Autoantibodies against beta-amyloid are common in Alzheimer's disease and help control plaque burden. Ann Neurol. 2009;65:24-31.

76. Butovsky O, Koronyo-Hamaoui M, Kunis G, et al. Glatiramer acetate fights against Alzheimer's disease by inducing dendriticlike microglia expressing insulin-like growth factor 1. Proc Natl Acad Sci U S A. 2006;103:11784-9.

77. Takata K, Kitamura Y, Saeki M, et al. Galantamine-induced amyloid\{beta\} clearance mediated via stimulation of microglial nicotinic acetylcholine receptors. J Biol Chem. 2010;285:40180-91.

78. Smith AM, Gibbons HM, Dragunow M. Valproic acid enhances microglial phagocytosis of amyloid-beta(1-42). Neuroscience. 2010;169:505-15.

79. Tolon RM, Nunez E, Pazos MR, et al. The activation of cannabinoid CB2 receptors stimulates in situ and in vitro beta-amyloid removal by human macrophages. Brain Res. 2009;1283:148-54.

80. Masoumi A, Goldenson B, Ghirmai S, et al. 1alpha,25-dihydroxyvitamin D3 interacts with curcuminoids to stimulate amyloid-beta clearance by macrophages of Alzheimer's disease patients. J Alzheimers Dis. 2009; 17:703-17.

81. Farfara D, Trudler D, Segev-Amzaleg N, et al. gamma-Secretase component presenilin is important for microglia beta-amyloid clearance. Ann Neurol. 2011;69:170-80.

82. Ruan L, Kang Z, Pei G, Le Y. Amyloid deposition and inflammation in APPswe/PS1dE9 mouse model of Alzheimer's disease. Curr Alzheimer Res. 2009;6:531-40.

83. Abbas N, Bednar I, Mix E, et al. Up-regulation of the inflammatory cytokines IFN-gamma and IL-12 and down-regulation of IL-4 in cerebral cortex regions of APP(SWE) transgenic mice. J Neuroimmunol. 2002;126:50-7.

84. Town T, Laouar Y, Pittenger C, et al. Blocking TGF-beta-Smad2/3 innate immune signaling mitigates Alzheimer-like pathology. Nat Med. 2008;14:681-7.

85. Zhu Y, Hou H, Rezai-Zadeh K, et al. CD45 deficiency drives amyloid-beta peptide oligomers and neuronal loss in Alzheimer's disease mice. J Neurosci. 2011;31:1355-65.

86. Hao W, Liu Y, Liu S, et al. Myeloid differentiation factor 88-deficient bone marrow cells improve Alzheimer's disease-related symptoms and pathology. Brain. 2011;134:278-92. 
87. Lee S, Varvel NH, Konerth ME, et al. CX3CR1 deficiency alters microglial activation and reduces beta-amyloid deposition in two Alzheimer's disease mouse models. Am J Pathol. 2010;177:2549-62.

88. Liu Z, Condello C, Schain A, et al. CX3CR1 in microglia regulates brain amyloid deposition through selective protofibrillar amyloidbeta phagocytosis. J Neurosci. 2010;30:17091-101.

89. Reed-Geaghan EG, Reed QW, Cramer PE, Landreth GE. Deletion of CD14 attenuates Alzheimer's disease pathology by influencing the brain's inflammatory milieu. J Neurosci. 2010;30:15369-73.

90. Song M, Jin J, Lim JE, et al. TLR4 mutation reduces microglial activation, increases Abeta deposits and exacerbates cognitive deficits in a mouse model of Alzheimer's disease. J Neuroinflammation. 2011;8:92.

91. Doi Y, Mizuno T, Maki Y, et al. Microglia activated with the toll-like receptor 9 ligand $\mathrm{CpG}$ attenuate oligomeric amyloid beta neurotoxicity in in vitro and in vivo models of Alzheimer's disease. Am J Pathol. 2009;175:2121-32.

92. Keene CD, Chang RC, Lopez-Yglesias AH, et al. Suppressed accumulation of cerebral amyloid beta peptides in aged transgenic
Alzheimer's disease mice by transplantation with wild-type or prostaglandin E2 receptor subtype 2-null bone marrow. Am J Pathol. 2010;177:346-54.

93. Terwel D, Steffensen KR, Verghese PB, et al. Critical role of astroglial apolipoprotein $\mathrm{E}$ and liver $\mathrm{X}$ receptor-alpha expression for microglial Abeta phagocytosis. J Neurosci. 2011;31:704959.

94. Fitz NF, Cronican A, Pham T, et al. Liver X receptor agonist treatment ameliorates amyloid pathology and memory deficits caused by high-fat diet in APP23 mice. J Neurosci. 2010;30: 6862-72.

95. Maier M, Peng Y, Jiang L, et al. Complement C3 deficiency leads to accelerated amyloid beta plaque deposition and neurodegeneration and modulation of the microglia/macrophage phenotype in amyloid precursor protein transgenic mice. J Neurosci. 2008;28:6333-41.

96. Chakrabarty P, Jansen-West K, Beccard A, et al. Massive gliosis induced by interleukin- 6 suppresses Abeta deposition in vivo: evidence against inflammation as a driving force for amyloid deposition. FASEB J. 2010;24:548-59. 